This is a self-archived version of an original article. This version may differ from the original in pagination and typographic details.

Author(s): Eskelinen Teppo; Ylönen Matti

Title: The Politics of Explanatory Nationalism and the Evolution of the United Nations Agenda on Multinational Enterprises

Year: 2020

Version: Published version

Copyright: (c) 2020 National Research University Higher School of Economics

Rights: In Copyright

Rights url: http://rightsstatements.org/page//nC/1.0/?language=en

Please cite the original version:

Eskelinen Teppo, Ylönen Matti. (2020). The Politics of Explanatory Nationalism and the Evolution of the United Nations Agenda on Multinational Enterprises. Vestnik mezhdunarodnih organizatsii, 15(3), 176-201. https://doi.org/10.17323/1996-7845-2020-03-07 


\title{
The Politics of Explanatory Nationalism and the Evolution of the United Nations Agenda on Multinational Enterprises
}

\section{T. Eskelinen, M. Ylönen}

Teppo Eskelinen - Department of social sciences and philosophy, University of Jyväskylä, Seminaarinkatu 15 , 40014, Finland. E-mail: teppo.h.i.eskelinen@jyu.fi.

Matti Ylönen - Faculty of social sciences / World politics, University of Helsinki, Yliopistonkatu 4, 00100, Finland. E-mail: matti.ylonen@helsinki.fi

\begin{abstract}
Social problems in the global South are often explained by reference to domestic decisions or "institutional quality" in the Southern countries, while there are also prominent criticisms of such "nationalist explanations". Crucially, the dispute over correct mode of explanation is not only epistemological, but also political, as has been often noted in analyses of hegemony. This paper develops such ideas about "hegemonic" forms of explanation by analysing how an explanatory tendency becomes institutionalised in the operating logic of international organisations. We analyse as a case study the long-term developments within the UN in the field of multinational enterprises (MNEs). We follow the process in which an agenda focused on the regulation of MNEs shifted into the direction of focusing on local institutional quality and emphasising "partnerships" instead of regulation. The analysis demonstrates how political momentum and external challenges affect explanatory tendencies, and generally the deep impact of organisational embeddedness of these tendencies.
\end{abstract}

Key words: Explanatory nationalism, multinational enterprises, United Nations, international organisations, hegemony, corruption

For citation: Eskelinen T. Ylönen M. (2020) The Politics of Explanatory Nationalism and the Evolution of the United Nations Agenda on Multinational Enterprises. International Organisations Research Journal, vol. 15, no 3, pp. (in English). DOI: 10.17323/1996-7845-2020-03-07

\section{What is Explanatory Nationalism?}

The contemporary world continues to suffer from a number of social problems that are global in scope but impact the Global South disproportionately. While broad and coordinated policy responses to overcome these problems exist, such policies are not shaped solely by the political will to address the problems. On the contrary, their content largely depends on how societies in general and the social problems in particular are routinely explained and conceptualized. We refer to these as explanatory tendencies or paradigms of explanation. As complex problems always have multiple root causes with long causal chains, explanations of these causes necessarily involve some assumptions about relevant causalities. Typically, the main choice in explaining international politics relates to the extent to which social phenomena should be explained by domestic institutions, decisions and events.

Social science in general has been noted to have a bias toward a "nationalist" approach to explanation [Beck, 2007; Brenner, 1999; Gore, 1993; Pogge, 2002]. This means treating the state as the primary and even sufficient object of analysis, so that problems are explained by the malfunctioning institutions and misinformed policies of states. Such 
explanatory biases become naturalized in everyday politics and social analysis [Amin, 2004]. While this has been widely discussed as an epistemological issue, the interplay between international organizations and explanatory tendencies has received less attention. The present article addresses this gap. We argue that explanatory tendencies and biases should not be treated exclusively as an epistemological matter. They need to be accompanied by an analysis of the role of international organizations as both influenced by an explanatory tendency and upholding it. Paradigms of explanation are reflected in the priorities and relative powers of international organizations, as their very structure can reflect particular explanatory tendencies. As an example, we will use the ascent and descent of the United Nations work on the power of multinational enterprises.

While the explanatory nationalist bias is often discussed in the literature, there are various theoretical traditions with different explanatory emphases. For example, International Relations (IR) scholars have discussed the caveats of the nationalist bias over several decades [Adamson, 2016; Brenner, 1999, 2001; Heiskanen, 2019; Kessler, 2012], although the impact of these critical insights on the mainstream neorealist and neoliberal IR scholarship has been limited. Mainstream theories of international relations not only narrow their focus to the interaction of states, but they also assume the states to be fairly contained, treating the state and society almost as synonyms [Chernilo, 2010; Walker 1993, 2010].

The nationalist approach also provides a starting point in theory of justice, as the domain of justice has typically been contained to the political community: distributive justice "presupposes a bounded world" [Walzer, 1983, p. 31]. Global justice is then typically conceptualized from this perspective, most famously in John Rawls' theorizing in which "peoples" are treated almost as if they were individuals acting within a "society of peoples" [Rawls, 2001]. As theories of justice and international relations are key theoretical backgrounds for analyzing global problems, such problems are often explained in nationalist terms.

The dependency school, critical international political economy literature and cosmopolitan IR theory, for their part, have adopted markedly non-nationalist approaches [Barnet, Müller, 1974; Beardsworth, 2011; Strange, 1970]. Dependency theorists argue that structural economic imbalances sustain poverty and other social ills in low-income countries: development in the Global North is enabled by underdevelopment in the Global South. This results from capital's geographical accumulation and the division of labour in global trade, which results in the economic periphery's deteriorating terms of trade relative to the economic core [Baran, 1962; dos Santos, 1970; Frank, 1966; Hopkins, Wallerstein, 1977; Koos, Keulman, 2019; Prebisch 1950]. Contemporary cosmopolitan theory focuses on the global community, and on interdependence more generally. Authors such as Charles Beitz [1979], Kok-Chor Tan [2004] and Thomas Pogge [1998, 2002] have argued that the political and economic world order contributes in many ways to the social condition of low-income countries. ${ }^{1}$

Belonging to the (loosely defined) category of cosmopolitan theorists, Pogge coined the influential concept of "explanatory nationalism," referring to the tendency to emphasize domestic factors and downplay extra-domestic factors when explaining problems such as extreme poverty [Pogge, 2002, 2001]. Explanatory nationalism comes close to the broader

\footnotetext{
${ }^{1}$ Naturally, not all theorists have sought to adopt either position in a strict manner. Some political philosophers, especially in the early 2000s, sought balance between the approaches [Tan, 2004; Haydar, 2005; Satz 2005].
} 
notion of "methodological nationalism" [Beck, 2007; Chernilo 2010, 2011], a "framework that seeks to explain national patterns and trends by reference to national factors" [Gore, 1993, p. 78]. This definition implies that sufficient explanations can be drawn from analyzing domestic factors in the design of questions, theoretical formulations and hypotheses; being particularly attentive to the domestic component of complex problems; constructing theoretical starting points with concepts referring exclusively to intra state matters; and systematically ignoring the role of factors external to the country. In general, the design of theories and methodologies takes for granted the state, its sovereignty and the powers of its government [Roche, 1992, pp. 184-5].

Especially in IR studies, there is a habit of grounding methodological nationalism on a substantialist ontology, which means that as entities, states are seen as preceding their interaction, only to be set into motion later [Jackson, Nexon, 1999]. According to authors who have criticized this dominant tendency, states should not be seen as having an ontological priority to relations; rather, connections between states "are the basis upon which the nation-state exists at all" [Giddens, 1987, pp. 263-4]: for instance, the very idea of territorial sovereignty was born out of the exploitative relations of Europeans with other nations [Anievas, Nişancioğlu, 2015]. Methodological nationalism not only incites disproportionate attention to states' internal processes, but it also leads to a situation where outcomes of deep interdependencies are treated as "external shocks" [Jackson, Nexon, 1999].

This nationalistic approach is visible both in theoretical and empirical research, as these inform and strengthen one another: theory informs problem formulation, and the aspects of empirical results that appear to confirm the theory often get highlighted in interpretation. These phenomena can be illustrated by focusing on the interplay between institutional theory and the idea of governance as ranking. This angle also expands analysis to the field of economics. The developments in mainstream IR have been greatly influenced by various economics-related approaches, from statistical analysis to game theory - as well as institutional theory [de Mesquita, Smith, 2012; Koos, Keulman, 2019].

Institutional theory aims to explain social and economic progress (and the lack of them) by the quality of national institutions. Institutions are seen to create mutual trust and foster a future perspective among people by clarifying and enforcing the norms of the society [Acemoglu, Robinson 2012; de Soto, 2000; North, 1990]. The institutional school argues that institutions "provide dependable property rights, manage conflict, maintain law and order, and align economic incentives with social costs and benefits" [Rodrik, 2003, p. 10]. Furthermore, they are "the rules of the game in a society or, more formally, are the humanly devised constraints that shape human interaction" [North, 1990, p. 3]. ${ }^{2}$ While institutional malfunction is sometimes seen also as an outcome of historical external factors such as colonialism [Acemoglu, Robinson, 2012], institutional theorists broadly find that domestic institutions provide sufficient explanations for social and economic progress in all countries.

The idea of performance as success in country rankings has recently gained popularity in organizing empirical data [Rotberg, 2018, p. 35]. Performance indicators ranking individual countries or public actors' achievements of given objectives [Bhuta, Malito, Umbach, 2018, p. 7] are routinely used to attract attention to the relative performance of countries in a given policy area [Kelley, Simmons, 2014, p. 4; Mügge, 2016]. While this can be done for various purposes and with different intentions, rankings enforce an idea of

\footnotetext{
${ }^{2}$ See also D. Landes [1998], D. Acemoglu, S. Johnson and J. Robinson [2002], and D. Rodrik, A. Subramanian and F. Trebbi [2004].
} 
countries as separate entities with different degrees of success in performance within given policy fields [Andrews, 2008; Broome, Quirk, 2015; Carroll, Jarvis, 2015; Kelley, Simmons, 2014; Thomas 2010]. ${ }^{3}$ Often such indicators are developed in cooperation between academics and international organizations. ${ }^{4}$

The former is a broad theoretical approach with significant power in explanation, while the latter is a method of organizing information on global issues. Neither of the approaches can be empirically refuted, nor is there anything empirically incorrect about them. They are merely perspectives for organizing and interpreting empirical information. Therefore, the limits of epistemology must be appreciated when choosing such approaches.

\section{Explanation, Epistemology and Organizations}

The critique of explanatory nationalism has been largely confined to the sphere of epistemology. Consequently, the problem of finding the adequate mode of explanation is seen as a challenge that should be resolved by epistemologically accurate arguments, for example by locating the most relevant causally contributing factors. Pogge [2002] implies that the task of philosophers is to put forward better arguments; ideally, the conflict between explanatory nationalism and explanatory cosmopolitanism could then be resolved on the level of mere argumentation. Explanation can then be seen as a matter of locating accurate causal chains [Brady, 2011], which can be analyzed, for example, by identifying counterfactual scenarios [Fearon, 2011]. The one exception recognized in Pogge's account is his idea that explanatory nationalism is morally comforting to the residents of the Global North. ${ }^{5}$

Yet, taking a conclusive position on different types of explanations for complex phenomena is often demanding. This difficulty is particularly acute in attempts to explain global problems. Finding a consensus over the most accurate explanation is highly unlikely. Rather, competing theories with different approaches can be simultaneously convincing within their theoretical frameworks. These frameworks include concepts, methodologies, ontologies and assumptions about the nature of social reality. Approaches like country rankings are not misguided in the sense of being refutable. Rather, they take as given the concepts and ontological approaches that guide the organizing of data.

Furthermore, explanatory models tend to be somewhat self-reinforcing, as already $\mathrm{T}$. S. Kuhn [2012] noted in his analysis of scientific paradigms. Observations are necessarily theory-laden and their interpretation often enforces the underlying theory, at least in the absence of major anomalies. Generally, differences in theories lead people to "see different things, make different interpretations of the way things are, and support different courses of

\footnotetext{
${ }^{3}$ One demonstration of the current power of indicators is how they attract public attention to policy issues. For example, the introduction of the United Nations Development Programme's (UNDP) Human Development Index facilitated the transformation from the 1980s structural adjustment programme era to a more pluralistic policy debate that also paid attention to human development [Stein, 2008, p. 23].

${ }^{4}$ As one example, the influential Corruption Perception Index was developed together with Transparency International and University of Passau [de Maria, 2008].

${ }^{5}$ The moral comfort arises from the fact that nationalist explanations enable citizens in the Global North to see themselves as assisting the global poor, rather than contributing to harming them. This dynamic is strengthened by the ways in which explanatory nationalism systematically downplays the role of these harmful contributions [Pogge, 2002].
} 
action concerning what is to be done" [Rein, Schön, 1993, p. 147]. For instance, explanations based on the market ontology tend to seek remedies to identified problems from imperfections in the functioning of markets (for an example, see A. Morgan [2020]).

Instead of eventually identifying the superior framework for explanation, the choice between nationalist and globalist explanations is affected by extra-scientific factors such as convention, individual preferences, and, ultimately, the broader political atmosphere. This does not mean that a politically powerful government could enforce any particular explanation to social problems. But, in certain political and institutional settings, some explanations become naturalized as dominant rationalities, referring to "the way problems are named and made understandable, attached to morality, and organised into spheres of knowledge" [Miller, Rose, 2008].

These remarks point to the need to analyze explanatory nationalism more broadly than in the confines of the epistemological framework. The role of explanations should be seen also as outcomes of long-lasting cultural and political developments, struggles and institutionalization, influenced by the interference of various policy-related and academic forms of knowledge production and transference. These processes can be conscious and deliberate, but they can also impose cultural and political ideas that have become naturalized in the current moment of time.

The neo-Gramscian school has become known for its analyses of the political aspects of social scientific knowledge production [Cox, 1983; Gill, Law, 1989; Morton, 2007]. NeoGramscian analysis revolves around the contents of a broad-based consent, or "the common sense," as expressions of hegemony. "Common sense" refers to the ideas that become accepted as natural and objective by mediating collective agency embedded in social practices [Rupert, 2003]. While such common sense is open to multiple interpretations, it nevertheless lays the ground for political explanation, thus determining explanatory hegemony. Neo-Gramscians analyze social reality as a constant struggle between ideas to achieve and maintain the status of common sense. The politics of dominance is then not merely a process of imposing power in the formal sense but also engaging in a cultural struggle to impose and continuously defend given ideas as "how the world works" [Kashwan, Maclean, García-López, 2019]. An often-cited recent example of such politics of dominance is the neoliberal turn in the 1980s, which became a turning point in dominance within the world of ideas, rather than only within formal politics [Owusu, 2003; Plehwe, 2007].

The struggle over hegemony is not limited to the sphere of ideas but involves a constant and complex interplay between explanations and organizations that develop and convey these explanations. Not only are political organizations informed by dominant explanatory tendencies, but explanatory tendencies are exacerbated by organizational practices and preferences. These organizational practices and preferences, in turn, become aligned with the dominant modes of explanation. Thereby, it is difficult to analyze the relations between explanations and politics in strictly causal terms (A causes B). The organizationally embedded common sense becomes self-reinforcing the same way as scientific paradigms do. Further, the mere existence of an organization can uphold an explanatory idea and broadly function against challenges to this common sense [Hale, Held, Young, 2013]. Therefore, attention must be paid to the ways in which ideas diffuse between research agendas on the one hand and the functioning, priorities and missions of organizations on the other [Ban, Gallagher, 2015]. Moreover, within international organizations, the dominant epistemic communities typically share common conceptions and modes of thinking about how the world works [Finnemore, Sikkink, 1998; Haas, 1992; 
Henriksen, Seabrooke, 2015]. This tendency is further strengthened by the transnational policy professionals' role as mediators and arbitrators of ideas, as they work in multiple roles in academia as well as in non-governmental and intergovernmental organizations [Bueger, 2014; Seabrooke, Wigan, 2016].

Generally, organizations produce ideas that align with their mandates and underlying path dependencies [Miller, Rose, 2008]. This dynamic is particularly visible in international politics, where organizations are often created in order to identify and respond to certain problems. This means that the very structure and mission of the organization reflects particular ideas about the sphere of explanation. The habit of following given explanatory tendencies further extends to the broader organizational constellation: while bodies with various approaches can exist, ones based on a hegemonic explanatory can sideline others in the daily practices of knowledge production and policymaking. Naturally, these organizations also need resources and political support, which are often associated with hegemonic positions.

Below, how explanatory nationalism works is analyzed from the theoretical perspective outlined above. To emphasize the significance of extra-epistemological factors, the object of analysis is called "the politics of explanatory nationalism." The object of analysis is a single exemplary case: the international turn from addressing the societal and political impact of multinational enterprises (MNEs) in the Global South to the good governance agenda in the 1970s-80s. How explanatory nationalism shaped the United Nations' (UN) approaches to MNEs is analyzed, demonstrating how explanatory nationalist and global tendencies change within organizations. This shift of approach within the international community was critical for the policy shift toward corporate responsibility, anticorruption and good governance agendas. Therefore, it can be seen as a critical case study that exemplifies the potential impact of similar major shifts in other policy fields.

Data is generated from official documents related to events that were important in reconstructing historical narratives. The main research material consists of various documents and reports issued by the UN Centre on Transnational Corporations (UNCTC). The reports were fetched from the website archive.org, given that the UNCTC's website is no longer operational. Other documents produced by the UN have also been used. This data is combined with an extensive literature review on the history of relevant UN bodies. The UNCTC published altogether 265 documents [Hamdani, Ruffing, 2015]. The material published on the internet is not comprehensive, but the most important reports and their supplementary materials were available and are included in the research material. Utilizing process tracing [Collier, 2011], the research material allowed the construction of a historical narrative of the key moments and elements in the rise and demise of the MNE agenda. The narrative is constructed especially around organizational turning points but pays attention also to the emergence of rationalities, launching events or "sparks," and possible contestation to rationalities and institutional priorities.

The emergence of the regulation of MNEs (transnational agents) on the UN policy agenda is analyzed first, showing how this agenda became institutionalized, how it became ideologically contested and how it was finally dissolved. This demonstrates how the good governance and anti-corruption agendas (as nationalist explanations) emerged as alternative explanatory frameworks. It also shows how parts of the existing criticism were successfully incorporated into this agenda, as the corporate responsibility agenda adopted a twisted version of explanatory cosmopolitanism. The purpose is to show how hegemonies were constructed both culturally and organizationally and how hegemonies resisted, or failed to 
resist, external criticism. This involves identifying key turning points and conditions for the institutionalization of given explanatory tendencies: a systematic categorization will be presented in the conclusions.

\section{Emergence of the Agenda on MNEs and Power}

The political and societal influence of MNEs emerged on the UN agenda by the 1970s, as decision makers began to grasp the impact of the rise of MNEs' power relative to the power of governments. In addition to the lack of policy-level attention, MNEs had been undertheorized, as most social sciences (including IR) had generally neglected their role [Strange, 1970; Ylönen, 2018]. The powers of MNEs were particularly visible when negotiating on prospective investments, as they began to expect perks (such as tax breaks); the MNEs also often have the upper hand over poorly resourced tax authorities, which enables them to shift their profits abroad with little or no taxes paid [Swank, 2016].

Yet the emergence of MNEs on the political agenda hardly resulted from a sudden realization of their impact. The ground was prepared by the increased global prominence of the broader development agenda, which pushed the UN to address the relationship between MNEs and developing countries in various resolutions in the early 1970s. This agenda was influenced by the developmentalist aspirations that had manifested in the UN's Economic Commission for Latin America and the Caribbean, as well as in other fora [Ylönen, 2018]. Yet the major spark to unleash the MNE-related agenda was a bribery scandal involving a major American multinational enterprise, ITT, which began to unravel in 1972. The case involved bribes that the company had offered to the Nixon administration to keep Salvador Allende out of power in Chile. The resulting public outrage provoked a series of U.S. Senate subcommittee hearings on not only the ITT incident but on a range of other issues related to American MNEs. As an example, critics accused Nestlé of dressing its salespeople to look like doctors and nurses to boost the sales of their breast milk substitutes [Moran, 2009, p. 92].

The policy-level and public attention was further bolstered by influential literature on MNEs, especially Jacques Servan-Schreiber's [1968] Le Defi Americain (The American Challenge), Kari Polanyi-Levitt's [2002, orig. 1970] Silent Surrender, and The Global Reach by Richard Barnet and Ronald Müller [1974]. These works addressed the potential threats of MNEs generally, in addition to specific themes such as the tax-avoiding opportunities of large MNEs. The subsequent policy developments contributed to the establishment of an organizational structure that relied on a highly internationalist conception of development and its counterforces. Within the UN, the July 1972 meeting of the Economic and Social Council (ECOSOC) turned out to be of particular importance, with Juan Somavía from Chile calling for a high-level expert commission to study MNE operations in developing countries [Katzarova, 2019]. According to the resolution, "the international community has yet to formulate a positive policy and establish effective machinery for dealing with the issues raised by the activities of these corporations."

The Group of Eminent Persons consisted of members from the public sector, public and private enterprises and the academy. Observers were invited from different UN agencies, the World Bank, and the International Monetary Fund (IMF). Raúl Prebisch, who has often been called the "Latin American Keynes" [Caldentey, Vernengo, 2015], contributed to the group's efforts as a consultant [Sagafi-nejad, Dunning, Perlmutter, 2008, p. 47]. The farreaching outcome report, entitled Multinational Corporations in World Development, was 
finalized in 1973. Among other things, the report highlighted a need for international regulation that would address MNEs' impact on the Global South. In addition, the report called for creating an international code of conduct, establishing an information centre within the UN to study MNEs, and setting up an international registry of MNEs [Chance, 1978; Rahman, 1998, p. 599].

The report was discussed in a hearing attended by several prominent corporate executives, government officials and academics. In conclusion, the UN decided to form the Commission of Transnational Corporations, which oversaw the UNCTC. The commission began operating as an autonomous UN centre in 1975. It was tasked to serve as the focal point on MNE-related issues within the UN, to draft a code of conduct and, if possible, also a general agreement on MNEs, and to undertake research and policy projects and to give policy advice [Chance 1978]. The centre was also tasked to provide support to the commission (and ultimately to ECOSOC), to develop an information system on MNEs' activities, to organize technical cooperation, and to conduct research on various economic, legal, political and social aspects of MNEs [Sagafi-nejad, Dunning, Perlmutter, 2008, p. 92].

K. Hamdani and L. Ruffing [2015, p. 15] argue that the performance of the UNCTC rested on four pillars. First, even though the centre was a part of the UN secretariat, its executive directors were highly independent: as one example of this independent mindset, the first executive director, Klaus Sahlgren, managed to negotiate an institutional arrangement where he reported directly to the UN's secretary-general. Second, recruitment decisions put strong emphasis on talent. Recruitment of world-class expertise in technical matters for shorter periods was prioritized over longer-term contracts with less prominent experts. Third, the centre recruited the best expertise in its substance areas internationally with short-term contracts. Fourth, voluntary contributions from members enabled fast responses to government requests for information and advice [Hamdani, Ruffing, 2015, p. 15].

The unfinished draft version of the document from 1983 illustrates the far-reaching nature of UNCTC's analyses [Commission on Transnational Corporations, 1996]. Among other things, the draft document stated that MNEs should "carry on their activities in conformity with the development policies, objectives and priorities set out by the Governments of the countries in which they operate," as well as in accordance with relevant intergovernmental agreements [Ibid., p. 153]. In addition, MNEs were supposed to respect the human rights and fundamental freedoms of the host countries, including nondiscrimination policies. Importantly, the corporations were also expected to refrain from interfering in both internal affairs of host countries, as well as in intergovernmental negotiations [Ibid., pp. 154-5]. The draft code of conduct also included an ambitious agenda on tackling tax avoidance and artificial profit shifting. Among other things, the document specified that MNEs should "not use pricing policies that are not based on relevant market prices, or, in absence of such prices, the arm's length principle, which have the effect of modifying the tax base on which their entities are assessed or of evading exchange control measures" [Ibid., p. 157].

Finally, the draft code of conduct included a highly ambitious section on the disclosure of information, demanding, for example, a "full and comprehensible information on the structure, policies, activities and operations of the transnational corporation as a whole" on both financial and non-financial items. This information should be broken down by geographical area or country-by-country level regarding activities of the MNE's main entities, operating results, sales, significant new investments and number of employees [Commission on Transnational Corporations 1996, p. 162]. The document also included 
requirements for cooperation in transfer of technology to host countries, as well as on consumer and environmental protection. ${ }^{6}$

To sum up, the emergence of the MNE agenda was facilitated by a given intellectual atmosphere and political mood (the dominant "common sense"), logical policy outcomes within the UN's organizational functioning, and an unleashing event. Explanatory cosmopolitanism guided the analysis of the underlying problems that sustained underdevelopment, as well as its remedies. The institutionalization of the dominant common sense was supported by the broadly accepted vantage point: namely, that MNEs can overpower states. This notion guided the definition of underlying problems that directed the UNCTC's work. Further, the UNCTC was equipped with sufficient organizational power (e.g. direct reporting) and prestige. This increased the role not only of the UNCTC's agenda specifically but also the general tendency to explain problems by reference to multinational factors - in line with explanatory cosmopolitanism.

\section{The Turn to Corporate Responsibility and Anti-Corruption Efforts}

The aforementioned organizational and epistemological setting collapsed by the 1980s. The ambitious MNE agenda gave way to an agenda that focused on good governance, drawing attention away from the possible negative impact of MNEs and foreign investments and focusing on malfunctioning institutions and petty corruption within poor countries. The background conditions that facilitated this turn included the general shift of political mood around the world, spearheaded by the election of Margaret Thatcher in Britain and Ronald Reagan in the United States. This was part of a broader development in the 1980s, where various regulatory initiatives became victims of the broader intellectual revolution of the time.

The Latin American debt crisis of 1982 was the spark that unleashed the change within the UN system. The Reagan government reacted to the debt crisis with institutional reform: its main goal was to turn the World Bank and the IMF into instruments for imposing structural adjustment programmes on indebted countries. This move was justified by a creative use of the body of economics literature on "rent seeking" by politicians and civil servants [Krueger, 1974; Stein, 2008], which paved ground for broader suspicion of civil servants and governments. Structural adjustment programmes played a key role in a shift of attitudes toward foreign enterprises in the Global South, as many countries started to experiment with more conciliatory approaches to foreign companies [Abrahams, 2005].

The institutionalization of this agenda was most notable in the growing importance of trade policy negotiations and treaties. This development was also exacerbated by the fact that both the International Labour Organization (ILO) and the Organisation for Economic Cooperation and Development (OECD) responded to the UNCTC's work by developing their own guidelines for MNEs in the 1970s. Both of these guidelines were significantly weaker than the one that UNCTC was working on. The OECD's and ILO's guidelines also suffered from poor implementation [Daniel et al., 2015]. Importantly, the UN also adopted a more conciliatory tone from the 1980s onward. The UNCTC and the Commission were dismantled

\footnotetext{
${ }^{6}$ Transfer of technology was also the subject of another code of conduct project under UN auspices, administered by UNCTAD. It faced a similar fate as the other projects discussed here.
} 
in 1992, right before the UN's Rio Earth Summit, which would be remembered for its remarkably strong corporate presence [Clapp, 2005]. Organizationally, the UNCTAD swallowed the UNCTC as a downgraded division in a process that was meant to be a merger of equals [Katzarova, 2019]. The code of conduct project was officially terminated. The UNCTAD's focus shifted increasingly from MNEs to the management and facilitation of foreign direct investment [Hamdani, Ruffing, 2015, p. 48].

Strikingly, the institutionalization of the new agenda did not attempt to hide the concerns that had led to the institutionalization of the UNCTC agenda. Rather, the agenda was neutralized by offering an alternative narrative with new kinds of rationalities and explanatory tendencies. This narrative was mostly based on the idea of the importance of "responsible corporate citizenship so that business can be part of the solution to the challenges of globalization" [Soederberg, 2007, p. 502]. In this narrative, a single agenda could be seen under "business and human rights" [Leisinger, Cramer, Natour, 2010, p. 26]. These narratives most visibly materialized in the UN-led partnership called the Global Compact, with a broad geographic scope and government support [Rasche, Kell, 2010, p. 5]. Moreover, a business-friendly approach was taken by the UN under Secretary-General Kofi Annan, who directed the UN to study matters such as transaction costs that occur in international business [Kell, 2005, p. 71].

The responsible corporate citizenship agenda relied on a twisted version of explanatory cosmopolitanism. In a way, the new agenda acknowledged the global presence and impact of MNEs. However, in contrast with earlier approaches, the new framework established that the greater presence of MNEs in the Global South was essentially a positive force. It just had to be tempered by the adoption of voluntary corporate responsibility guidelines. However, the responsible corporate citizenship agenda was not sufficient to provide a comprehensive explanatory framework. One of its weaknesses was an absence of analysis on the factors that hindered development in the Global South.

In this respect an important development was the way in which the emergence of the corporate responsibility agenda coincided with the emergence of a coordinated, international policy push against corruption [Ylönen, 2019]. Corruption was added as the 10th pillar of the first version of the Global Compact in 2004. It can be argued that the triumph of the anticorruption agenda on the one hand and the human rights and business agenda on the other hand sealed the demise of the policy agenda on corporate power. Hence, it also enabled combining a private sector-driven version of explanatory cosmopolitanism (the responsible corporate citizenship agenda) with an explanatory nationalist accounting of the underlying root causes of global inequality. As argued below, this explanatory nationalistic understanding of corruption was essential for the triumph of the explanatory cosmopolitan version of the corporate citizenship agenda.

While scholars have discussed corruption at least since the 1960s, it was only during the 1980s — and especially during the 1990s — that the issue started to gather broader attention. Illustratively, Robert Klitgaard noted in 1988 that at that time, the international development literature was "surprisingly silent" about corruption [p. 6]. In the early days of international development, corruption was often even seen as necessary to tackle bureaucratic regulations in newly decolonized countries.

The existing political mood shaped the ways in which corruption became understood and framed as a problem. Corruption can be defined in various ways, and the differences between these definitions illustrate the normative aspects of this concept. Corruption can be 
understood as everything from a broad array of dubious practices through which civil servants and politicians enrich themselves to the practice of paying bribes in return for some favour, or, ultimately, as "any abusive use of public power to a personal end" [Amundsen, 1999, p. 1]. As Arvind Jain has noted, "how corruption is defined actually ends up determining what gets modeled and measured" [Jain, 2001, p. 73]. According to a classic definition, corruption is "behaviour which deviates from the formal duties of a public role because of private-regarding (personal, close family, private clique) pecuniary or status gains; or violates rules against the exercise of certain types of private-regarding influence" (J. S. Nye, quoted in J. Amundsen [1991, p. 2]). Alternatively, "corruption exists when an individual illicitly puts personal interests above those of the people and ideals he or she is pledged to serve" [Klitgaard, 1988, p. xi]. ${ }^{7}$

Importantly, corruption can be approached in either a cosmopolitan or nationalist way. While corruption as such is open to being understood as an outcome of unacceptable conduct from the (often transnational) private sector, many definitions omit the responsibility of the private sector in sustaining corruption almost entirely. For instance, Toke Aidt [2009, p. 271] defines corruption simply as the "sale of government property for private gain." While corruption could (and should) be seen as a transnationally organized phenomenon, corruption discourse is characterized by an inherent methodological nationalism, as corruption tends to be conceived and measured in discrete bordered national units [Cooley, 2018, pp. 51-2].

By the 1970s, a widely shared understanding emerged in the United States that U.S. corporations were paying bribes to foreign government officials in hope of obtaining sales commissions or procurement contracts or sales commissions. A special presidential task force and the Securities and Exchange Commission studied the issue, leading to new requirements for more transparent internal auditing [Gathii, 2009]. As the cosmopolitan regulatory agenda for MNEs gave way to the anti-corruption agenda, such malpractices became to be seen as a set of domestic problems in countries with corrupt governments. The increasing prominence of institutional theory in international organizations assisted this turn.

The major turn toward the domestically focused anti-corruption agenda took place in the 1990s. The economic thinking behind structural adjustment programmes of the World Bank and the IMF had facilitated the emergence of the good governance agenda, which stipulated that public sector failures are a major impediment for development in Africa. The initial focus on trade policy deregulation, privatization and macroeconomics was gradually extended to anti-corruption work.

While the anti-corruption agenda addressed real, existing problems that hampered human and economic development in many countries, it was also conducive in shifting the attention from global corporate malpractices to state failures in implementing the good governance agenda. In line with the earlier examples, the anti-corruption agenda also created and sustained academic and policy communities that helped to promote and further develop the agenda. However, in contrast with the UNCTC-centred efforts to regulate corporate

\footnotetext{
${ }^{7}$ Klitgaard saw corruption as a problem both for the public and the private sector. However, especially compared to the earlier corporate power approaches, his book presented an important step in shifting the focus of discussion from corporate power to public sector failures.
} 
power efforts, the anti-corruption agenda was in line with the hegemonic positions of the (post-) structural adjustment era.

It was not enough for the new agenda to be institutionalized, it also needed to be successful in incorporating and neutralizing the growing criticism. Toward the late 1990s, the impact of MNEs and corporate malpractice became again a heated topic, with large demonstrations at the WTO meeting in Seattle in 1999, and subsequent meetings. This criticism could have acted as a spark to reformulate the organizational setting and the related rationalities and tendencies of explanation. However, it proved difficult to change the underlying practices [Stephen 2011], as the voluntary responsibility agenda had become the one tool to show that the policy community was addressing concerns. The UN's Global Compact emerged as a compromise solution, calling on participating companies to "support and respect the protection of international human rights within their sphere of influence" and to "make sure that they are not complicit in human rights abuses" [Leisinger, Cramer, Natour, 2010, p. 26].

The international aspects of corruption only started to re-emerge in academic and policy-level discussions in the 2000s. This was illustrated, for example, by work undertaken by Transparency International related to the role of the private sector in facilitating corruption [Fagan, Hearson, 2015]. However, the common sense that emphasized domestic factors in governance and its misuse resulted in at least two decades of neglect toward the role of the private sector and its facilitators (including tax havens) in underdevelopment and corruption [Christensen, 2011; Picciotto, 2007; Ylönen, 2018]. The 2010s have seen a major uptick in studies that focus on the facilitators and users of corruption, accompanied by an international policy agenda [Aalbers, 2018; Hudson, 2020; Linstead, Maréchal, Griffin, 2014; O'Hara, 2014]. However, the ways in which explanatory nationalism hindered these efforts in earlier decades remain poorly understood.

\section{Conclusions}

This article undertook a detailed theoretical discussion of explanatory nationalism, along with related concepts, highlighting a tendency to explain severe economic and social problems in low-income countries by excessive reference to their domestic institutions and domestic policies. Noting the existence of such explanatory bias, it was argued that the notion of explanatory nationalism needs to be pushed further by analyzing its institutionalized aspects and the interplay between international organizations and explanatory tendencies.

Therefore, the struggle over dominant explanations does not take place only in the spheres of social science and epistemology but also within concrete political organizations. While the tone of international organizations is often ethical ("this is a problem we need to address"), typically more important is how the problem is framed in terms of agency, responsibility and the "natural" set of remedies. Hegemonic explanations also tend to be selfreinforcing: theories and observations inform each other, and past events get re-evaluated from the perspective of the new hegemony. ${ }^{8}$ Explanatory nationalism is not just an epistemological starting point but an institutionalized tendency to base remedies to problems on a given rationality.

\footnotetext{
${ }^{8}$ See C. Gore [1993] on the re-interpretation of the East Asian economic policies.
} 
The "correct" level of explanation is empirically unresolvable, as there are various overlapping spheres of contributing factors to social problems. Hence, the choice of abstraction and description of key agents is also a political one. The issue should then be seen as a concrete institutional process in which an explanatory mode is enforced and becomes perceived as natural. Such a process is always an interplay between organizations and ideas. Explanatory tendencies should also be seen as political in the sense of being concrete alternatives to other explanations: practically, the good governance agenda also has had the function of shifting attention to domestic issues. ${ }^{9}$

The examples analyzed above display a process in which international consensus on the root causes of global inequality gravitated toward an explanatory nationalist tendency. An exception to this tendency was the voluntary regulation of MNEs, which relied on a twisted version of explanatory cosmopolitanism. While policy-level debates that draw from globalist explanations of global inequalities exist and even have an organizational backing, international politics often adopts a focus on domestic failures, corruption, good governance and domestic institutions generally, as it searches for remedies to economic and social problems. The accompanying emergence of a twisted version of explanatory cosmopolitanism can even make it harder to articulate cosmopolitan explanatory frameworks that are driven by public interest.

In the reconstructed narrative of the MNE agenda within the UN, the political working of explanatory tendencies was analyzed, considering the interplay of several factors. First is the prevailing common sense (or, ideological preparation) pushing for given kinds of issues to be seen as problems and given kinds of remedies being suggested as "natural." Second are the organizationally embedded rationalities which often end up being selfreinforcing. This self-reinforcement is both epistemological (observation is informed by theory and thereby often supports the underlying theory) and organizational (organizations have a defined mission, which includes ideas on problems and suitable remedies). Third are external events ("sparks") which frame a given issue as an acute problem and require response. Fourth is the contestation from outside, leading to incorporation of the protest, or remaking the organizational setting. There can be build ups of background conditions but they fail to materialize because of organizational resistance. Organizations can also absorb and incorporate agendas without changing the underlying explanatory approach.

Explanatory tendencies can be seen as outcomes of a complex dynamic consisting of an interplay between these four factors. Organizations have been particularly emphasized as sites of explanatory patterns: while hegemony theory looks at how ideas become dominant, it should be noted that dominance of ideas at least on the level of world politics requires organizations that materialize these ideas in their rationale of operation. While the analysis in this article focused on a single example, it is worth noting that ideas that emerge from the UN system tend to have broader significance [Weiss, 2010]. This analysis could also be extended to other international organizations, such as the Bretton Woods institutions, or perhaps the OECD. This framework could also be extended to analyze other thematic issues.

\footnotetext{
${ }^{9}$ The dominant, nationally focused corruption agenda has further been said to "perform the crucial task of restoring faith in the western ideals of liberal democracy, rule of law, and development" [Rajagopal, 1999, pp. 498-9].
} 


\section{References}

Aalbers M. B. (2018) Financial Geography I: Geographies of Tax. Progress in Human Geography, vol. 42, no 6, pp. 916-27. Available at: https://doi.org/10.1177\%2F0309132517731253.

Abrahams D. (2005) Regulations for Corporations: A Historical Account of TNC Regulation. Available at: https://www.business-humanrights.org/en/latest-news/doc-regulations-forcorporations-a-historical-account-of-tnc-regulation/ (accessed 31 August 2020).

Acemoglu D., Johnson S., Robinson J. (2002) The Colonial Origins of Comparative Development: An Empirical Investigation. American Economic Review, vol. 91, no 5, pp. 1369-401. Available at: https://doi.org/10.1257/aer.91.5.1369.

Acemoglu D., Robinson J. A. (2012) Why Nations Fail: The Origins of Power, Prosperity and Poverty. New York: Crown Publishers.

Adamson F. B. (2016) Spaces of Global Security: Beyond Methodological Nationalism. Journal of Global Security Studies, vol. 1, no 1, pp. 19-35. Available at: https://doi.org/10.1093/jogss/ogv003.

Aidt T. S. (2009) Corruption, Institutions, and Economic Development. Oxford Review of Economic Policy, vol. 25, no 2, pp. 271-91. Available at: https://doi.org/10.1093/oxrep/grp012.

Amin A. (2004) Regions Unbound: Towards a New Politics of Place. Geografiska Annaler Series B: Human Geography, vol. 86, no 1, pp. 33-44. Available at: https://doi.org/10.1111/j.0435-3684.2004.00152.x.

Amundsen I. (1999) Political Corruption: Introduction to the Issues. Chr. Michelsen Institute Working Paper No 1999:7. Available at: https://www.cmi.no/publications/file/1040-politicalcorruption.pdf (accessed 31 August 2020).

Andrews M. (2008) The Good Governance Agenda: Beyond Indicators Without Theory. Oxford Development Studies, vol. 36, no 4, pp. 379-407. Available at: https://doi.org/10.1080/13600810802455120.

Anievas A., Nişancioğlu K. (2015) How the West Came to Rule: The Geopolitical Origins of Capitalism. London: Pluto Press. Available at: https://www.jstor.org/stable/j.ctt183pb6f.

Ban C., Gallagher K. (2015) Recalibrating Policy Orthodoxy: The IMF Since the Great Recession. Governance, vol. 28, no 2, pp. 131-46. Available at: https://doi.org/10.1111/gove.12103.

Baran P. (1962 [1957]) The Political Economy of Growth. New York: Monthly Review Press.

Barnet R. J., Müller R. E. (1974) Global Reach: The Power of the Multinational Corporations. New York: Simon and Schuster.

Beardsworth R. (2011) Cosmopolitanism and International Relations Theory. Cambridge: Polity. 
Beck U. (2007) The Cosmopolitan Condition: Why Methodological Nationalism Fails. Theory, Culture \& Society, vol. 24, no 7-8, pp. 286-90. Available at: https://doi.org/10.1177\%2F02632764070240072505.

Beitz C. (1979) Political Theory and International Relations. Princeton: Princeton University Press.

Bhuta N., Malito D. V., Umbach G. (2018) Introduction: Of Numbers and Narratives: Indicators in Global Governance and the Rise of a Reflexive Indicator Culture. The Palgrave Handbook of Indicators in Global Governance (D. V. Malito, G. Umbach, N. Bhuta (eds)). London: Palgrave.

Brady H. E. (2011) Causation and Explanation in Social Science. The Oxford Handbook of Political Science (R. E. Goodin (ed)). Oxford: Oxford University Press.

Brenner N. (1999) Beyond State-Centrism? Space, Territoriality, and Geographical Scale in Globalization Studies. Theory and Society, vol. 28, no 1, pp. 39-78. Available at: https://www.jstor.org/stable/3108505.

Brenner N. (2001) The Limits to Scale? Methodological Reflections on Scalar Structuration. Progress in Human Geography, vol. 25, no 4, pp. 591-614. Available at: https://doi.org/10.1191\%2F030913201682688959.

Broome A., Quirk J. (2015) Governing the World at a Distance: The Practice of Global Benchmarking. Review of International Studies, vol. 41, no 5, pp. 819-41. Available at: https://doi.org/10.1017/S0260210515000340.

Bueger C. (2014) From Expert Communities to Epistemic Arrangements: Situating Expertise in International Relations. International Relations and the Global Politics of Science and Technology (M. Mayer, M. Carpes, R. Knoblich (eds)). Dortrecht: Springer.

Caldentey E. P., Vernengo M. (2015) Reading Keynes in Buenos Aires: Prebisch and the Dynamics of Capitalism. Cambridge Journal of Economics, vol. 40, no 6, pp. 1725-41. Available at: https://doi.org/10.1093/cje/bev074.

Carroll T. C., Jarvis D. S. L. (2015) The New Politics of Development: Citizens, Civil Society, and the Evolution of Neoliberal Development Policy. Globalizations, vol. 12, no 3, pp. 281-304. Available at: https://doi.org/10.1080/14747731.2015.1016301.

Chance S. K. (1978) The Code of Conduct for Multinational Corporations. Business Lawyer, vol. 33, no 3, pp. 1799-1820. Available at: https://www.jstor.org/stable/40685882.

Chernilo D. (2010) Methodological Nationalism and the Domestic Analogy: Classical Resources for Their Critique. Cambridge Review of International Affairs, vol. 23, no 1, pp. 87-106. Available at: https://doi.org/10.1080/09557570903433654.

Chernilo D. (2011) The Critique of Methodological Nationalism: Theory and History. Thesis Eleven, vol. 106, no 1, pp. 98-117. Available at: https://doi.org/10.1177\%2F0725513611415789. 
Christensen J. (2011) The Looting Continues: Tax Havens and Corruption. Critical Perspectives on International Business, vol. 7, no 2, pp. 177-96. Available at: https://doi.org/10.1108/17422041111128249.

Clapp J. (2005) Global Environmental Governance for Corporate Responsibility and Accountability. Global Environmental Politics, vol. 5, no 3, pp. 23-34. Available at: https://doi.org/10.1162/1526380054794916.

Collier D. (2011) Understanding Process Tracing. PS: Political Science and Politics, vol. 44, no 4, pp. 823-30. Available at: https://doi.org/10.1017/S1049096511001429.

Commission on Transnational Corporations (1996) Draft United Nations Code of Conduct on Transnational Corporations. International Investment Instruments: A Compendium. UNCTAD: Geneva. Available at: XXX

Cooley A. (2018) How International Rankings Constitute and Limit Our Understanding of Global Governance Challenges: The Case of Corruption. The Palgrave Handbook of Indicators in Global Governance (D. V. Malito, G. Umbach, N. Bhuta (eds)). London: Palgrave.

Cox R. W. (1983) Gramsci, Hegemony, and International Relations: An Essay in Method. Millennium: Journal of International Studies, vol. 12, no 2, pp. 162-75. Available at: https://doi.org/10.1177\%2F03058298830120020701.

Daniel C., Wilde-Ramsing J., Genovese K., Sandjojo V. (2015) Report: Remedy Remains Rare. OECD Watch. Available at: https://www.oecdwatch.org/wpcontent/uploads/sites/8/2015/06/Remedy-Remains-Rare.pdf (accessed 31 August 2020).

de Maria W. (2008) Measurements and Markets: Deconstructing the Corruption Perception Index. International Journal of Public Sector Management, vol. 21, no 7, pp. 777-97. Available at: https://doi.org/10.1108/09513550810904569.

de Mesquita B. B., Smith A. (2012) Domestic Explanations of International Relations. Annual Review of Political Science, vol. 15, pp. 161-81. Available at: https://doi.org/10.1146/annurev-polisci-070209-174835.

de Soto H. (2000) The Mystery of Capital: Why Capitalism Triumphs in the West and Fails Everywhere Else. New York: Bantam Books.

dos Santos T. (1970) The Structure of Dependence. American Economic Review, vol. 60, no 2, pp. 231-6. Available at: https://www.jstor.org/stable/1815811.

Fagan C., Hearson M. (2015) Tax Systems: A Channel for Corruption - Or a Way to Fight It? Working Paper No 03/2015, Transparency International. Available at: https://images.transparencycdn.org/images/2015_WorkingPaper3_TaxSystems_EN.pdf (accessed 31 August 2020).

Fearon J. D. (2011) Counterfactuals and Hypothesis Testing in Political Science. World Politics, vol. 43, no 2, pp. 169-95. Available at: https://doi.org/10.2307/2010470. 
Finnemore M., Sikkink K. (1998) International Norm Dynamics and Political Change. International Organization, vol. 52, no 4, pp. 887-917. Available at: https://www.jstor.org/stable/2601361.

Frank A. G. (1966) The Development of Underdevelopment. Monthly Review, vol. 18, no 4, pp. 17-31. Available at: https://www.jstor.org/stable/188950.

Gathii J. T. (2009) Defining the Relationship Between Human Rights and Corruption. University of Pennsylvania Journal of International Law, vol. 31, no 1, pp. 125-202. Available at: https://scholarship.law.upenn.edu/jil/vol31/iss1/3 (accessed 31 August 2020).

Giddens A. (1987) The Nation-State and Violence. Berkeley: University of California Press.

Gill S., Law D. (1989) Global Hegemony and the Structural Power of Capital. International Studies Quarterly, vol. 33, no 4, pp. 475-99. Available at: https://doi.org/10.2307/2600518.

Gore C. (1993) Methodological Nationalism and the Misunderstanding of East Asian Industrialization. European Journal of Development Research, vol. 8, no 1, pp. 77-122. Available at: https://doi.org/10.1080/09578819608426654.

Haas P. M. (1992) Introduction: Epistemic Communities and International Policy Coordination. International Organization, vol. 46, no 1, pp. 1-35. Available at: https://doi.org/10.1017/S0020818300001442.

Hale T., Held D., Young K. (2013) Gridlock: Why Global Cooperation Is Failing When We Need It Most. Hoboken: Wiley.

Hamdani K., Ruffing L. (2015) United Nations Centre on Transnational Corporations: Corporate Conduct and the Public Interest. London: Routledge.

Haydar B. (2005) Extreme Poverty and Global Responsibility. Metaphilosophy, vol. 36, no 12, pp. 240-53. Available at: https://doi.org/10.1111/j.1467-9973.2005.00365.x.

Heiskanen J. (2019) Spectra of Sovereignty: Nationalism and International Relations. International Political Sociology, vol. 13, no 3, pp. 315-32. Available at: https://doi.org/10.1093/ips/olz007.

Henriksen L. F., Seabrooke L. (2015) Transnational Organizing: Issue Professionals in Environmental Sustainability Networks. Organization, vol. 23, no 5, pp. 722-41. Available at: https://doi.org/10.1177\%2F1350508415609140.

Hopkins T. K., Wallerstein I. (1977) Patterns of Development of the Modern World-System. Review, vol. 1, no 2, pp. 111-45. Available at: https://www.jstor.org/stable/40240765.

Hudson R. (2020) The Illegal, the Illicit and New Geographies of Uneven Development. Territory, Politics, Governance, vol. 8, no 2, pp. 161-72. Available at: https://doi.org/10.1080/21622671.2018.1535998.

Jackson P. T., Nexon D. H. (1999) Relations Before States: Substance, Process and the Study of World Politics. European Journal of International Relations, vol. 5, no 3, pp. 291-332. Available at: https://doi.org/10.1177\%2F1354066199005003002. 
Jain A. K. (2001) Corruption: A Review. Journal of Economic Surveys, vol. 15, no 1, pp. 71121. Available at: https://doi.org/10.1111/1467-6419.00133.

Kashwan P., Maclean L. M., García-López G. A. (2019) Rethinking Power and Institutions in the Shadows of Neoliberalism. World Development, vol. 120, special issue. Available at: https://doi.org/10.1016/j.worlddev.2018.05.026.

Katzarova E. (2019) The Social Construction of Global Corruption: From Utopia to Neoliberalism. London: Palgrave.

Kell G. (2005) The Global Compact: Selected Experiences and Reflections. Journal of Business Ethics, vol. 59, pp. 69-79. Available at: https://doi.org/10.1007/s10551-005-3413-0.

Kelley J. G., Simmons B. A. (2014) The Power of Performance Indicators: Rankings, Ratings and Reactivity in International Relations. Washington DC: American Political Science Association.

Kessler O. (2012) World Society, Social Differentiation and Time. International Political Sociology, vol. 6, no 1, pp. 77-94. Available at: https://doi.org/10.1111/j.17495687.2012.00151.x.

Klitgaard R. (1988) Controlling Corruption. Berkeley: University of California Press.

Koos A. K., Keulman K. (2019) Methodological Nationalism in Global Studies and Beyond. Social Sciences, vol. 8, no 12. Available at: https://doi.org/10.3390/socsci8120327.

Krueger A. O. (1974) The Political Economy of the Rent-Seeking Society. The American Economic Review, vol. 64, no 3, pp. 291-303. Available at: https://www.jstor.org/stable/1808883.

Kuhn T. S. (2012) The Structure of Scientific Revolutions. Chicago: University of Chicago Press.

Landes D. (1998) The Wealth and Poverty of Nations: Why Some Are So Rich and Some So Poor. New York: Norton.

Leisinger K., Cramer A., Natour F. (2010) Making Sense of the United Nations Global Compact Human Rights Principles. The United Nations Global Compact: Achievements, Trends and Challenges (A. Rasche, G. Kell (eds)). Cambridge: Cambridge University Press.

Linstead S., Maréchal G., Griffin R. W. (2014) Theorizing and Researching the Dark Side of Organization. Organization Studies, vol. 35, no 2, pp. 165-88. Available at: https://doi.org/10.1177\%2F0170840613515402.

Miller P., Rose N. (2008) Governing the Present: Administering Social and Personal Life. Cambridge: Polity.

Moran T. H. (2009) The United Nations and Transnational Corporations: A Review and Perspective. Transnational Corporations, vol. 18, no 2, pp. 91-112. Available at: https://doi.org/10.18356/d3e73f33-en. 
Morgan J. (2020) A Critique of the Laffer Theorem's Macro-Narrative Consequences for Corporate Tax Avoidance From a Global Wealth Chain Perspective. Globalizations, online version. Available at: https://doi.org/10.1080/14747731.2020.1760420.

Morton A. (2007) Unravelling Gramsci. Hegemony and Passive Revolution in the Global Political Economy. London: Pluto Press.

Mügge D. (2016) Studying Macroeconomic Indicators as Powerful Ideas. Journal of European Public Policy, vol. 23, no 3, pp. 410-27. Available at: https://doi.org/10.1080/13501763.2015.1115537.

North D. (1990) Institutions, Institutional Change, and Economic Performance. Cambridge: Cambridge University Press.

O'Hara P. A. (2014) Political Economy of Systemic and Micro-Corruption Throughout the World. Journal of Economic Issues, vol. 48, no 2, pp. 279-308. Available at: https://doi.org/10.2753/JEI0021-3624480203.

Owusu F. (2003) Pragmatism and the Gradual Shift From Dependency to Neoliberalism: The World Bank, African Leaders and Development Policy in Africa. World Development, vol. 31, no 10, pp. 1655-72. Available at: https://doi.org/10.1016/S0305-750X(03)00136-0.

Picciotto S. (2007) The International Crisis of Income Taxation: Combating Tax Havens, Capital Flight and Corruption. Paper presented at the Critical Legal Conference, Kent, February.

Plehwe D. (2007) A Global Knowledge Bank? The World Bank and Bottom-Up Efforts to Reinforce Neoliberal Development Perspectives in the Post-Washington Consensus Era. Globalizations, vol. 4, no 4, pp. 514-28. Available at: https://doi.org/10.1080/14747730701695786.

Pogge T. (1998) The Bounds of Nationalism. Canadian Journal of Philosophy, vol. 22 (supplementary), pp. 463-504. Available at: https://doi.org/10.1080/00455091.1997.10716825.

Pogge T. (2001) The Influence of the Global Order on the Prospects for Genuine Democracy in the Developing Countries. Ratio Juris, vol. 14, no 3, pp. 326-43. Available at: https://doi.org/10.1111/1467-9337.00185.

Pogge T. (2002) World Poverty and Human Rights. Cosmopolitan Responsibilities and Reforms. Cambridge: Polity.

Polanyi-Levitt K. (2002) Silent Surrender: The Multinational Corporation in Canada. Montreal: McGill-Queen's University Press.

Prebisch R. (1950) The Economic Development of Latin America and Its Principal Problems. Document E/CN.12/89/REV.1, Economic Commission for Latin America, United Nations Department of Economic Affairs. Available at: https://repositorio.cepal.org/handle/11362/29973 (accessed 2 September 2020). 
Rahman S. F. (1998) International Accounting Regulation by the United Nations: A Power Perspective. Accounting, Auditing \& Accountability Journal, vol. 11, no 5, pp. 593-623. Available at: https://doi.org/10.1108/09513579810239864.

Rawls J. (2001) The Law of Peoples. Cambridge: Harvard University Press.

Rajagopal B. (1999) Corruption, Legitimacy and Human Rights: The Dialectic of the Relationship. Connecticut Journal of International Law, vol. 14, pp. 495-507. Available at: https://ssrn.com/abstract=940042 (accessed 2 September 2020).

Rasche A., Kell G. (2010) Introduction. The United Nations Global Compact: Achievements, Trends and Challenges. Cambridge: Cambridge University Press.

Rein M., Schön D. (1993) Reframing Policy Discourse. The Argumentative Turn in Policy Analysis and Planning (F. Fischer, J. Forester (eds)). London: University College London Press.

Roche M. (1992) Rethinking Citizenship: Welfare Ideology and Change in Modern Society. Cambridge: Polity Press.

Rodrik D., Subramanian A., Trebbi F. (2004) Institutions Rule: The Primary of Institutions Over Geography and Integration in Economic Development. Journal of Economic Growth, vol. 9, no 2, pp. 131-65. Available at: https://www.jstor.org/stable/40212696.

Rodrik D. (ed) (2003) In Search of Prosperity: Analytical Narratives on Economic Growth. Princeton: Princeton University Press.

Rotberg R. I. (2018) Good Governance: Measuring the Performance of Governments. The Palgrave Handbook of Indicators in Global Governance (D. V. Malito, G. Umbach, N. Bhuta (eds)). London: Palgrave.

Rupert M. (2003) Globalising Common Sense: A Marxian-Gramscian (Re)Vision of the Politics of Governance/Resistance. Review of International Studies, vol. 29, pp. 181-98. Available at: https://www.jstor.org/stable/20097891.

Sagafi-nejad T., Dunning J. H., Perlmutter H. V. (2008) The UN and Transnational Corporations: From Code of Conduct to Global Compact. Bloomington: Indiana University Press.

Satz D. (2005) What Do We Owe the Global Poor? Ethics \& International Affairs, vol. 19, no 1, pp. 47-54. Available at: https://doi.org/10.1111/j.1747-7093.2005.tb00489.x.

Seabrooke L., Wigan D. (2016) Powering Ideas Through Expertise: Professionals in Global Tax Battles. Journal of European Public Policy, vol. 23, no 3, pp. 357-74. Available at: https://doi.org/10.1080/13501763.2015.1115536.

Servan-Schreiber J. J. (1968) The American Challenge. New York: Atheneum.

Soederberg S. (2007) Taming Corporations or Buttressing Market-Led Development? A Critical Assessment of the Global Compact. Globalizations, vol. 4, no 4, pp. 500-13. Available at: https://doi.org/10.1080/14747730701695760. 
Stein H. (2008) Beyond the World Bank Agenda: An Institutional Approach to Development. Chicago: University of Chicago Press.

Stephen M. (2011) Globalisation and Resistance: Struggles Over Common Sense in the Global Political Economy. Review of International Studies, vol. 37, no 1, pp. 209-28. Available at: http://www.jstor.org/stable/23024591.

Strange S. (1970) International Economics and International Relations: A Case of Mutual Neglect. International Affairs, vol. 46, no 2, pp. 304-15. Available at: https://doi.org/10.2307/2613829.

Swank D. (2016) The New Political Economy of Taxation in the Developing World. Review of International Political Economy, vol. 23, no 2, pp. 185-207. Available at: https://doi.org/10.1080/09692290.2016.1155472.

Tan K.-C. (2004) Justice Without Borders. Cosmopolitanism, Nationalism, and Patriotism. Cambridge: Cambridge University Press.

Thomas M. A. (2010) What Do the Worldwide Governance Indicators Measure? European Journal of Development Research, vol. 22, no 1, pp. 31-54. Available at: https://doi.org/10.1057/ejdr.2009.32.

Walker R. B. J. (1993) Inside/Outside: International Relations as Political Theory. Cambridge: Cambridge University Press. Available at: https://doi.org/10.1017/CBO9780511559150.

Walker R. B. J. (2010) After the Globe, Before the World. Routledge: London. Available at: https://doi.org/10.4324/9780203871249.

Walzer M. (1983) Spheres of Justice. A Defence of Pluralism and Equality. New York: Basic Books.

Weiss T. G. (2010) How United Nations Ideas Change History. Review of International Studies, vol. 36, no S1, pp. 3-23. Available at: https://doi.org/10.1017/S026021051100009X.

Ylönen M. (2018) Planned Economies? Corporations, Tax Avoidance and World Politics. $\mathrm{PhD}$ Dissertation, University of Helsinki. Available at: https://core.ac.uk/download/pdf/158132329.pdf.

Ylönen M. (2019) Who's to Blame for the Money Drain? Corporate Power and Corruption as Competing Narratives for Lost Resources. Tax, Inequality and Human Rights (P. G. Alston, N. Reisch (eds)). Oxford: Oxford University Press. 